\title{
Enhancing Primary ESL Learners' Simple Sentence Construction Using the PPT PiWoCa Technique in the Form of Bubble Map-A Literature Review
}

\author{
Winson Eng Wei Siang1, Yong Hua Ying2, Maslawati Mohamad ${ }^{3}$ \\ ${ }^{1}$ Sekolah Jenis Kebangsaan Cina Ladang Grisek, Johor, Malaysia \\ ${ }^{2}$ Department of General Studies, Politeknik Mukah, Sarawak, Malaysia \\ ${ }^{3}$ Faculty of Education, Universiti Kebangsaan Malaysia, Bangi, Malaysia \\ Email: winsonews@gmail.com,yonghuaying8071@gmail.com, maslawati@ukm.edu.my
}

How to cite this paper: Siang, W. E. W., Ying, Y. H., \& Mohamad, M. (2021). Enhancing Primary ESL Learners' Simple Sentence Construction Using the PPT PiWoCa Technique in the Form of Bubble Map-A Literature Review. Creative Education, 12, 1458-1468.

https://doi.org/10.4236/ce.2021.127111

Received: June 6, 2021

Accepted: July 5, 2021

Published: July 8, 2021

Copyright $\odot 2021$ by author(s) and Scientific Research Publishing Inc. This work is licensed under the Creative Commons Attribution International License (CC BY 4.0).

http://creativecommons.org/licenses/by/4.0/

\begin{abstract}
Society of today signifies how English, as a global language, has attained a universal pedestal compared to others. Thus, it is highly demanding and challenging for one to be a proficient and effective language user. In Malaysia, teachers of English as a Second Language (ESL) tend to face umpteenth challenges in developing primary ESL learners' language abilities, especially in the scope of writing. Some of the problems include deprivation of vocabulary, lack of motivation, lack of reading and the influence of multimedia language. Consequently, ESL teachers have to opt for different strategies and approaches to tackle primary ESL learners' writing skills, particularly in simple sentence construction. Therefore, this study presents a literature review on the use of PowerPoint Picture-Word Card (PPT PiWoCa) technique in the form of bubble map to enhance primary ESL learners' simple sentence construction. In this study, social constructivist theory and the visual-spatial element in Gardner's Multiple Intelligences theory reveal that the PPT PiWoCa technique allows primary ESL learners to brainstorm ideas and construct knowledge in authentic contexts. Similarly, the use of visual representations such as PPT, pictures, word cards and bubble map is able to capture primary ESL learners' attention in the recognition of words, grammatical functions and sentence structure based on a guided sample of simple sentence construction. With the presence of visual aids, primary ESL learners are able to model the sample given in order to produce meaningful simple sentences.
\end{abstract}

\section{Keywords}

Writing, Challenges, Primary ESL Learners, PPT, Pictures, Word Cards, Bubble 
Map, Simple Sentence Construction

\section{Introduction}

Having known that many language empires have come and gone across the counterpart of human history, Bennett and de Barros (2017) articulate that none of them have attained a universal pedestal enjoyed by English in the current age. According to Ushioda (2017), today's societies around the globe signify the extent to which global English achieves elementary skill status for English towards primary learners of English as a second language (ESL) upon entering education. It is remarkable to note that the teaching and learning of English should lead to primary ESL learners' mastery of the four language domains: listening, speaking, reading and writing. Eventually, primary ESL learners can and will communicate with the community using both oral and written language forms fluently, proficiently and effectively (Khusnul, 2020).

To specify, writing is one language skill that cannot be neglected or ostracised. It is also one of the most challenging skills to be mastered as it is taught from basic to complex. According to Durga and Rao (2018), primary ESL learners often encounter difficulties when conveying their thoughts in written work. Apart from that, short message system (SMS) is another hindrance that affects primary ESL learners' writing abilities. The emergence of multimedia technology, as pointed out by Indrajith and Varghese (2018), has resulted in greater writing dilemmas. Abbreviations or informal phrases such as "brb—be right back", "ikr-I know right" and "btw-by the way" are some examples that clearly dictate the inability of primary ESL learners when constructing simple sentences in the target language. Other writing conundrums faced by primary ESL learners also include deprivation of vocabulary, lack of grammar knowledge awareness, poor conventions in writing, lack of reading exposure and deficient motivation.

In the teaching spectrum, the ability to teach writing effectively on primary ESL learners is of paramount importance among English language teachers. On this pertinent accord, a great number of ramifications leading to primary ESL learners' poor academic performance can be observed if their foundation in writing has not been firmly established (Moses \& Maslawati, 2019). Moreover, some researchers on similar studies have examined that good writing skills are prerequisites for primary ESL learners not only to fulfil their educational requirements, but also employability at large (Khusnul, 2020; Moses \& Maslawati, 2019; Durga \& Rao, 2018). Likewise, Durga and Rao (2018) have thoroughly elaborated some of the functions emanating the essential of writing skills: 1) to submit technical documents or research papers, 2) for job applications, 3) to make presentations or reports, 4) to enhance social skills and 5) to boost imagination and discovery for self-understanding.

As a result, English language teachers need to be aware of the challenges faced 
by primary ESL learners, particularly in the acquisition of writing skills. Therefore, this paper aims to provide a literature review on enhancing primary ESL learners' simple sentence construction using the PPT PiWoCa technique in the form of bubble map.

\section{Literature Review}

According to Morthy and Aziz (2020), writing is perceived as a means of dispatch that empowers primary ESL learners to deliver their ideas, opinions and emotions through a well-planned text. Since the complexity of writing in its dimensions and manifestations has grown tremendously over the decades (Bazerman, Graham, Applebee, Matsuda, Berninger, Murphy, \& Schleppegrell, 2017), study populations have taken into account primary ESL learners and marginalised circles with diversified language experiences. Competence in writing, on the arbitrary line, happens in almost all spheres of action where its development is often intertwined with personal and intellectual trajectories that constitute to individual uniqueness (Bazerman et al., 2017).

In line with the government's policy on strengthening English, the Malaysian Education Blueprint 2013-2025 has been launched to highlight the niche area on the implementation of the present curriculum (Ien, Melor, \& Embi, 2017). The process of writing and rewriting as described by Johnson (2017) serves as a principle of how writing might render primary ESL learners with the space to construct, expand and claim identity. Hence, it is crucial for English language teachers to play a pivotal role on imparting the necessary skills expected of primary ESL learners prior to writing.

\subsection{Emphasis on Writing Skills}

According to Kucharská and Veverková (2012) as reviewed in Kučerová and Kucharská (2018), the development of writing differs from an individual learner to another. They continue to add that individual skills of a young learner in conditions for writing, personal qualities and learning experiences in the field of art are some of the variables pertaining to writing progression. Thereafter, writing is an indispensable skill that is definitely beneficial to all primary ESL learners. As such, English language teachers at the grassroots level are obligated to derive a plethora of engaging activities that can pique and gauge primary ESL learners' interest and motivation.

The conventions in writing do enable primary ESL learners to grasp a strong groundwork when it comes to simple sentence construction. These include the elements of penmanship, capitalisation, punctuation, spelling rules, style and register (Durga \& Rao, 2018). In this regard, English language teachers should encourage primary ESL learners to persist in the pursuit of writing, be it formal or informal. Furthermore, the types of writing avenue should be made available and versatile to the primary ESL learners such as story, blog, diary and journal writing. 
In congruence with this, writing possesses some core values in alliance with interpersonal development. According to a research by Abdullah and Melor (2019), primary ESL learners are adventurous risk-takers in the writing process. The reason being is they collaborate with their peers in expressing ideas using the correct grammar and vocabulary, specifically in rigorous discussions. Instant feedback given by primary ESL learners projects as a focal point on their writing improvements. By virtue, it is imperative that writing de facto connects primary ESL learners' schemata with their learning ambience, thus peripheral learning can be optimised.

Patiño, Calixto, Chiappe and Almenarez (2020) justify that the pervasive incorporation of Information and Communication Technologies (ICT) in writing assists primary ESL learners to build words, acquire a lexicon and collectively create coherent sentences and texts. With the current existence of salient technology, several studies on ICT in the subject of writing have reported that there is a proliferation in the usage of blog and online diaries among teenagers (Patiño et al., 2020; Yüce, 2020). Mansouri (2017) also highlights that blog writing as a form of Internet-based resource, acts as a genuine and motivating learning tool in many educational contexts, especially within primary ESL classrooms. Similarly, Zabala-Vargas, Parra-Valencia, Lizcano-Reyes, Zabala-Vargas and Dallos (2019) rationalise the infusion of ICT is meant for primary ESL learners to create proficiency to access, premeditate, analyse and synthesise high-quality information. Linking to its subsequent effect, the development of writing skill among primary ESL learners should provide an epiphany of integral contribution to society's knowledge, so that they keep abreast with the tenets in writing to improve the quality of education.

\subsection{Challenges Faced by Primary ESL Learners in Writing}

Each primary ESL learner may encounter different problems when it comes to writing. As writing is a dynamic process, these challenges would certainly be hurdles for one to produce a good piece of writing. Subsequently, the following paragraphs will outline some of the major challenges faced by primary ESL learners in writing.

One of the challenges is insufficient vocabulary. According to Saengpakdeejit (2014) as cited in Hasan (2016), primary ESL learners often perceive unknown words as the first problem to overcome. This is because inadequacy of vocabulary knowledge may lead to difficulties in Second Language Acquisition (SLA). In addition, Huy (2015) consolidates that writing is undoubtedly a good method to help polish primary ESL learners' abilities of applying vocabulary, thus ameliorating the capabilities of using the language. With a solid background of vocabulary knowledge, primary ESL learners will then be able to transmit their thoughts in a more meaningful way, the written form in particular.

Frequent errors on spelling and punctuation is another predicament faced by primary ESL learners in writing. English writing, as elucidated by Shweba and 
Mujiyanto (2017), involves distinctive technicalities and principles. In this respect, primary ESL learners find writing challenging as they always struggle with the fundamental transcription protocols. Similarly, Huy (2015) claims that they do not identify a good piece of writing with appropriate use of spelling and punctuation. A couple of researchers topple to that by substantiating that primary ESL learners activate their native tongue in the language production instead of the target language, which is synonymous to direct translation (Atayeva, Putro, Kassymova, \& Kosbay, 2019; Belkhir \& Benyelles, 2017). Ergo, most of the statements produced by them make no sense or are difficult to decipher. In turn, primary ESL learners deviate the awareness on the importance of writing skill on their second language learning. As a consequence, spelling and punctuation are vital elements that make the written tasks well.

Lack of grammar accuracy and awareness is an extenuating factor contributing to writing concerns among primary ESL learners. Despite the shift of communicative approach in SLA, grammar component in primary ESL learners' writing is deemed as a prime indicator of their language proficiency and intelligibility in academic settings (Yang, 2018). Many researchers support the claim that grammar entails a systematic structure which provides detailed information and meaning of a writer to a reader (Yang, 2018; Hinkel, 2013; Hegelheimer \& Fisher, 2006). On the contrary, Annisa Astrid, Marzulina, Amirul Mukminin, Dian Erlina, Ni'matul Ajriyah, Muhamad Holandiyah and Akhmad Habibi (2019) argue that lack of grammar comprehension might hamper communication in productive skills. They also rationalise that English grammar occupies a central position in language learning (Annisa Astrid et al., 2019). Hence, mastering grammar of language is the essence that will impact the mastery of writing skills, in the case at hand to be exact.

According to Atayeva et al. (2019), dearth of reading ensues an impactful issue on primary ESL learners' writing skills. Undeniably, having a positive attitude towards reading helps develop primary ESL learners to be problem solvers and critical thinkers. In tandem with this, Raimes (1994) as cited in Atayeva et al. (2019) stresses that better readers are better writers. Corresponding to that, Kroll (1997) as reviewed in Hasan (2016) signifies it is reading that gives the writer the feel and mood for the look. In order to achieve competence in writing, reading should implicitly dictate the core sample and model for primary ESL learners to emulate and appreciate. All in all, deprived reading is among the sources that can cause dissatisfaction in writing among primary ESL learners.

It is also apparent that lack of motivation could lead to failure in writing among primary ESL learners. Belkhir and Benyelles (2017) extrapolate several factors that prevent primary ESL learners from writing: 1) level of anxiety, 2) fear of failure, 3) fear of committing mistakes and 4) uncertainties. All these factors are often associating with motivation, just as pointed out by Pineteh (2013), primary ESL learners are generally bewildered about the objective and significance in their second language learning. While their writing patterns can be re- 
shaped through extended practice and empowerment of linguistic knowledge, writing abilities among primary ESL learners can undoubtedly be improved by fostering their enthusiasm and motivation for writing (Fareed, Ashraf, \& Bilal, 2016). Most importantly, English language teachers should resort to a multitude of strategies and provide constructive feedback instantaneously in the promotion of writing, so that primary ESL learners' confidence is elevated (Fareed, Ashraf, \& Bilal, 2016).

\subsection{The Use of PPT PiWoCa Technique in the Form of Bubble Map to Teach Simple Sentence Construction}

According to Abdullah and Melor (2019), English language teachers should take into consideration the use of instructional media to capture primary ESL learners' attention in the classroom. One of common media is pictures. Qishta (2017) describes pictures as a visual representation which acts as a catalyst to help reduce primary ESL learners' cognitive loads. To add, Abdullah and Melor (2019) support that pictures are valuable sources for English language teachers because they come in many forms to help primary ESL learners generate ideas. On a parallel note, Apsari (2017) encourages the use of pictures since it can stimulate and provide information in an either objective or subjective manner. In this context, the use of pictures allows primary ESL learners to brainstorm ideas in authentic contexts so that they are able to apply appropriate words when constructing simple sentences in the target language.

Krisdiana, Irawati and Kadarisman (2018) delineate word cards as a helpful tool in connecting form and meaning of a target word. Supported by a growing body of research, the effectiveness of word cards is evident because Wilkinson (2017) has spelt out a variety of features to be given credit to the use of word cards including: 1) expanding rehearsal for reiteration of words, 2) active recall of the ESL word form and its meaning and 3) eliminating serial learning. Pursuant to this, word cards are able to capture primary ESL learners' attention in the recognition of words, grammatical functions and sentence structure based on a guided sample of simple sentence construction. In brief, word or vocabulary cards are highly recommended to teach simple sentence construction as they are time efficient and easy to use, especially teaching primary ESL learners.

Apart from that, there are eight I-think maps for English language teachers to select according to the suitability of context. One of the I-think maps such as the bubble map has placed a greater emphasis on the teaching and learning of writing among primary ESL learners. According to Manoli and Papadopoulou (2012) as cited in Maharani (2019), bubble maps are useful in assessing primary ESL learners' degree of understanding and enhancing memory retention of the main ideas. Adjacently, with the presence of bubble maps, primary ESL learners' ideas can be formed in a more structured manner, which will result in the improvement on their writing (Fadillah, 2019). It is therefore necessitous for Eng- 
lish language teachers to cultivate primary ESL learners' thinking by adopting bubble maps aptly in the teaching-learning of simple sentence construction.

With the advancement of science and technology in this digital age, English language teachers are compelled to acquire the ability to integrate ICT into their teaching and learning. In this regard, they should nurture the competency of primary ESL learners' improvements to meet the demand of lifelong learning. Aziz and Dewi (2020) highlight PowerPoint as one of the technological tools commonly used by English language teachers as the media of learning. According to Azizah, Wajdi, Farida, Junus, Harianti, Chusna and Zuono (2019), the use of PowerPoint brings a large number of benefits. Some of them are: a) stable, b) easy to function, c) can cater for large class sizers and d) possesses interesting effects and transitions. However, Uzun and Kilis (2019) postulate that PowerPoint can appear to be a threat in learning. For instance, redundancy of content, overcomplicated charts, inappropriate background and too much on-screen text in the presentation may lead to English language teachers' deficiency on content delivery and primary ESL learners' passivity. Hence, such a modality should be used in a subtle fashion so that the teaching and learning of simple sentence construction among primary ESL learners are not made verbatim.

Despite the variants, the process approach has been chosen to be discussed as it is apt for the concern of this study of PPT PiWoCa technique in the form of Bubble Map. Randaccio (2013) states that guidance via the process approach is preferable to assist primary ESL learners on their writing skills. Process approach covers the stages of planning, drafting, revising and editing. For instance, upon employing this PPT PiWoCa technique, primary ESL learners will have to discuss and brainstorm ideas before constructing the sentences which falls under the process of planning. During the discussion period, some will tend to jot down or draft their discussion points. Along the way, they will communicate and exchange views to see if they are on the right track in constructing the sentences correctly which falls under the process of revising. Based on a given sample of simple sentence construction, primary ESL learners will also have to make necessary corrections to their sentences upon their discussion which signifies the process of editing.

\subsection{Underpinning Theories}

Social constructivist theory by Vygotsky is one of the underlying theories in this technique. According to Shukla (2014), constructivists conceive that learners build their own knowledge where learning takes place based on past experiences. In other words, this theory suggests that primary ESL learners are able to make meaning out of the information they have created or formed. Through the application of PPT PiWoCa technique in the form of bubble map, primary ESl learners have the abilities to construct information independently and will remember the information more meaningfully. On another perspective, Aljohani (2017) illuminates that learning is a form of social interaction that involves 
communication, authentic situations and collaboration among learners in a social norm according to the constructivist theory. The implementation of this technique provides opportunities for primary ESL learners to interact with their peers when constructing knowledge based on the topic assigned. In this context, primary ESL learners are more receptive to colours, shapes and forms when they are exposed to the PPT PiWoca technique in the form of bubble map.

The Multiple Intelligences (MI) Theory advocated by Gardner offers a unique concept on intelligence and has a philosophy of mind which recognizes many different sides of thinking processes (Safranj, 2018). The eight intelligences are verbal/linguistic, logical/mathematical, visual/spatial, bodily-kinaesthetic, musical, interpersonal, intrapersonal and naturalistic intelligences. With regard to this study, the visual/spatial element is significant to address the writing issues faced by primary ESL learners. Visual/spatial intelligence prevails the potential of the mind in creating a mental image which exposes the spatial world. Safranj (2018) further explains that primary ESL learners are more likely to explore the interpretation and creation of visual images, pictorial imagination and expression. Hence, this technique embeds the use of pictures and word cards in the form of bubble map to assist primary ESL learners' construction of simple sentences which adheres to the visual/spatial intelligence.

\section{Conclusion and Implications}

This study is to explore the literature review on the use of PPT PiWoCa technique in the form of bubble map to enhance primary ESL learners' simple sentence construction. It can be summarised that this technique has proven its effectiveness to a certain extent in helping primary ESL learners improve their writing abilities. The existing literature has identified the emphasis on writing skills, challenges faced by primary ESL learners in writing, the use of PPT PiWoCa technique in the form of bubble map and underpinning theories to teach simple sentence construction among primary ESL learners.

By understanding the aspects put forth in writing, especially simple sentence construction, various stakeholders should play their roles respectively in reassuring the success of using such technique on primary ESL learners. More so, English language teachers who are the core agents in this field of study, could choose the best possible approach to deal with writing skill. Thus, the use of visual representations such as PPT, pictures, word cards and bubble map is able to capture primary ESL learners' attention in the recognition of words, grammatical functions and sentence structure based on a guided sample of simple sentence construction. With the presence of visual aids, primary ESL learners are able to model the sample given in order to produce meaningful simple sentences. Ultimately, it is the onus of the English language teachers to strike a balance between the juxtaposition of both obsolete and technological teaching materials in order to tackle, motivate, encourage and inspire primary ESL learners to write. 


\section{Conflicts of Interest}

The authors declare no conflicts of interest regarding the publication of this paper.

\section{References}

Abdullah, Y. L. P. K., \& Melor, M. Y. (2019). The Use of Pictures in Improving Students' Writing. Modern Journal of Language Teaching Methods (MJLTM), 1-8.

Aljohani, M. (2017). Principles of "Constructivism" in Foreign Language Teaching. Journal of Literature and Art Studies, 7, 97-107. https://doi.org/10.17265/2159-5836/2017.01.013

Annisa Astrid, N., Marzulina, L., Amirul Mukminin, A., Dian Erlina, D., Ni'matul Ajriyah, N. M., Muhamad Holandiyah, H., \& Akhmad Habibi, H. (2019). The Grammatical Awareness of Student Teachers: The Case of an English Education Study Program in Indonesia. Universal Journal of Educational Research, 7, 1847-1859. https://doi.org/10.13189/ujer.2019.070902

Apsari, Y. (2017). The Use of Picture Series in Teaching Writing Recount Text. ELTIN Journal: Journal of English Language Teaching In Indonesia, 5, 51-56. https://doi.org/10.22460/eltin.v5i2.p51-56

Atayeva, M., Putro, N. H. P. S., Kassymova, G., \& Kosbay, S. (2019). Impact of Reading on Students' Writing Ability. Materials of International Practical Internet Conference Challenges of Science, Indonesia, November 2019, 5-13. https://doi.org/10.31643/2019.001

Aziz, I. N., \& Dewi, Y. A. S. (2020). The Use of PowerPoint as Media of Language Teaching on Students' Speaking Skill. Humanities \& Social Sciences Reviews, 8, 344-358. https://doi.org/10.18510/hssr.2020.8145

Azizah, S., Wajdi, M. B. N., Farida, U., Junus, D., Harianti, I., Chusna, S. N. L., \& Zuono, T. T. (2019). Blog Implications as Learning Media in Improving Learning Achievement of Students. Journal of Physics, 1175, 12260. https://doi.org/10.1088/1742-6596/1175/1/012260

Bazerman, C., Graham, S., Applebee, A. N., Matsuda, P. K., Berninger, V. W., Murphy, S., \& Schleppegrell, M. (2017). Taking the Long View on Writing Development. Research in the Teaching of English, 51, 351-360.

Belkhir, A., \& Benyelles, R. (2017). Identifying EFL Learners Essay Writing Difficulties and Sources: A Move towards Solution the Case of Second Year EFL Learners at Tlemcen University. International Journal of Learning, Teaching and Educational Research, $16,80-88$.

Bennett, K., \& de Barros, R. Q. (2017). International English: Its Current Status and Implications for Translation. The Translator, 23, 363-370. https://doi.org/10.1080/13556509.2017.1385939

Durga, V. S. S., \& Rao, C. S. (2018). Developing Students' Writing Skills in English: A Process Approach. Journal for Research Scholars and Professionals of English Language Teaching, 6, 1-5.

Fadillah, R. (2019). Students' Perception on the Use of Mind Mapping Application Software in Learning Writing. A Journal of Culture, English Language Teaching, Literature and Linguistics, 6, 58-64. https://doi.org/10.22219/CELTICUMM.Vol6.No1.58-64

Fareed, M., Ashraf, A., \& Bilal, M. (2016). ESL Learners' Writing Skills: Problems, Factors and Suggestions. Journal of Education and Social Sciences, 4, 81-92. 
https://doi.org/10.20547/jess0421604201

Hasan, L. N. K. (2016). The Effect of Lack of Vocabulary on English Language Learners' Performance with Reference to English Departments Students at Salahaddin University-Erbil. Journal of Pure and Applied Sciences, 20, 211-227.

Hegelheimer, V., \& Fisher, D. (2006). Grammar, Writing, and Technology: A Sample Technology-Supported Approach to Teaching Grammar and Improving Writing for ESL Learners. CALICO Journal, 23, 257-279. https://doi.org/10.1558/cj.v23i2.257-279

Hinkel, E. (2013). Research Findings on Teaching Grammar for Academic Writing. English Teaching, 68, 3-21. https://doi.org/10.15858/engtea.68.4.201312.3

Huy, N. T. (2015). Problems Affecting Learning Writing Skill of Grade 11 at Thong Linh High School. Asian Journal of Educational Research, 3, 53-69.

Ien, L. K., Melor, M. Y., \& Embi, M. A. (2017). Build Me Up: Overcoming Writing Problems among Pupils in a Rural Primary School in Belaga, Sarawak, Malaysia. Jurnal Pendidikan Humaniora, 5, 1-7. https://doi.org/10.17977/um030v5i12017p001

Indrajith, I., \& Varghese, T. (2018). Language into "Lang": Whatsapp Imprints on Teenagers. Acme International Journal of Multidisciplinary Research, 6, 71-82.

Johnson, L. P. (2017). Writing the Self: Black Queer Youth Challenge Heteronormative Ways of Being in an After-School Writing Club. Research in the Teaching of English, 52, 13-33.

Khusnul, K. (2020). Improving Students' Writing Skill through Mind Mapping Strategy. IAIN Jember, 1 Jun, 4.

Krisdiana, B. P., Irawati, E., \& Kadarisman, A. E. (2018). The Effectiveness of Role-Play Integrated with Word Cards on Students' Speaking Skill for Communication. Jurnal Pendidikan Humaniora, 6, 78-84.

Kučerová, O., \& Kucharská, A. (2018). Acquiring Penmanship and Writing Skills from the First to Fifth Grade of Primary School: Joined-Up Writing vs. Comenia Script. Journal of Language and Cultural Education, 6, 1-13. https://doi.org/10.2478/jolace-2018-0012

Maharani, M. M. (2019). Color-Coded Graphic Organizer for Empowering Students' Writing. ELLiC 2019: Proceedings of the 3rd English Language and Literature International Conference, Semarang, 27 April 2019, 90. https://doi.org/10.4108/eai.27-4-2019.2285375

Mansouri, N. (2017). Algerian EFL Students' Perceptions towards the Development of Writing through Weblog-Writing. Journal of Humanities and Cultural Studies R\&D, 2, $1-7$.

Morthy, D. K., \& Aziz, A. A. (2020). The Use of Language Games in Enhancing ESL Learners' Sentence Construction. Sciences, 10, 16-32. https://doi.org/10.6007/IJARBSS/v10-i9/7695

Moses, R. N., \& Maslawati, M. (2019). Challenges Faced by Students and Teachers on Writing Skills in ESL Contexts: A Literature. Creative Education, 10, 3385-3391. https://doi.org/10.4236/ce.2019.1013260

Patiño, J. F., Calixto, A. L., Chiappe, A., \& Almenarez, F. T. (2020). ICT-Driven Writing and Motor Skills: A Review. International Electronic Journal of Elementary Education, 12, 489-498. https://doi.org/10.26822/iejee.2020562139

Pineteh, E. (2013). Research Report on the Language Challenges Experienced by International Students at Cape Peninsula University of Technology. Unpublished Research Report, Cape Town: Cape Peninsula University of Technology.

Qishta, F. M. (2017). The Effectiveness of Using Pictures on Developing Sentence Writing 
Skills for the Seventh Graders in the Governmental Schools in Rafah. Doctoral Dissertation.

Randaccio, M. (2013). Writing Skills: Theory and Practice. ISSN Journal.

Safranj, J. (2018). Spatial-Visual Intelligence in Teaching Students of Engineering. Research in Pedagogy, 8, 71-83. https://doi.org/10.17810/2015.72

Shukla, S. (2014). Construction of Knowledge among Young Children before Their Entry to School. Journal of Humanities and Social Science (IOSR-JHSS), 19, 88-92. https://doi.org/10.9790/0837-19538892

Shweba, A. A. A., \& Mujiyanto, Y. (2017). Errors of Spelling, Capitalization, and Punctuation Marks in Writing Encountered by First Year College Students in Al-Merghib University Libya. English Education Journal, 7, 93-103.

Ushioda, E. (2017). The Impact of Global English on Motivation to Learn other Languages: Toward an Ideal Multilingual Self. The Modern Language Journal, 101, 469-482. https://doi.org/10.1111/modl.12413

Uzun, A. M., \& Kilis, S. (2019). Impressions of Preservice Teachers about Use of PowerPoint Slides by Their Instructors and Its Effects on Their Learning. International Journal of Contemporary Educational Research, 6, 40-52. https://doi.org/10.33200/ijcer.547253

Wilkinson, D. (2017). EFL Vocabulary Acquisition through Word Cards: Student Perceptions and Strategies. TESL-EJ, 21, 3.

Yang, H. (2018). Efficiency of Online Grammar Checker in English Writing Performance and Students' Perceptions. Korean Journal of English language and Linguistics, 18, 328-348. https://doi.org/10.15738/kjell.18.3.201809.328

Yüce, E. (2020). Keeping Online Diary as an Integrated Activity for Developing Writing Skill in EFL Classes through Penzu. Bartın University Journal of Faculty of Education, 9, 132-140.

Zabala-Vargas, S., Parra-Valencia, J., Lizcano-Reyes, R., Zabala-Vargas, J., \& Dallos, A. L. (2019). Effect of Information and Communication Technologies in the Development of Reading and Writing Skills. Experiences in Basic and Secondary Education in Columbia. 11th International Conference on Education and New Learning Technologies, Palma, 1-3 July 2019, 7704-7712. https://doi.org/10.21125/edulearn.2019.1865 